\title{
Motivasi Berprestasi Sebagai Mediasi Pada Hubungan Antara Dukungan Sosial dan Keterlibatan Siswa di Sekolah
}

\author{
Nur Saqinah Galugu ${ }^{1}$, Amriani $^{2}$ \\ ${ }^{1}$ Bimbingan Konseling STKIP Muhammadiyah Palopo, Indonesia \\ Email: saqina.galugu@gmail.com \\ ${ }^{2}$ PG-PAUD, STKIP Muhammadiyah Palopo, Indonesia \\ Email: amriani25@yahoo.com
}

\begin{abstract}
Abstrak. Penelitian ini bertujuan untuk memberikan pemahaman kepada seluruh profesional disekitar siswa seperti orangtua, guru dan teman sebaya tentang pentingnya mendorong motivasi siswa yang akan mempengaruhi tingkat keterlibatan siswa di sekolah. Tujuan khusus dari penelitian ini yakni menguji hubungan antara dukungan sosial dan keterlibatan siswa di sekolah yang dimediasi oleh motivasi berprestasi. Penelitian ini merupakan penelitian korelasional. Variabel mediasi adalah motivasi berprestasi diukur denganthe Achievement Motive Scale. Data dianalisa dengan menggunakan nalisis jalur. Subjek penelitian yakni siswa kelas XII Sekolah Menengah Atas Negeri 3 Palopo sebanyak 120 orang siswa dipilih dengan menggunakan teknik proportional sampling. Hasil penelitian menunjukkan bahwa terdapat hubungan positif yang signifikan antara dukungan sosial, motivasi berprestasi dan keterlibatan siswa di sekolah. Sedangkan motivasi berprestasi tidak menjadi mediasi pada hubungan tersebut, hal tersebut dilihat dari angka hubungan langsung yang lebih besar dibandingkan hubungan tidak langsung.
\end{abstract}

\section{Kata Kunci: Dukungan Sosial, Motivasi Berprestasi, Keterlibatan Siswa}

\begin{abstract}
This research aims to give an understanding to all professionals around the students', such as their parents, teachers, and peers about the importance of stimulating the students' motivation so that they will engage in some particular school activities. The specific purpose of this study is to examine the correlation between the social support and students engagement at school mediated by achievement motivation. This research is a correlational research. Veriable mediation is an achievement motivation measured by Achievement Motive Scale. Data were analyzed by using the path analysis method. Participants were 120 students of senior high school number 3 Palopo selected by using the proportional sampling technique. The results showed that there was a significant positive correlation among social support, achievement motivation, and studentsengagement. While achievement achievement motivation can not be functioned as the mediator on the relationship of social support and student engagement, it is shown from the direct correlation which is greater than the indirect one.
\end{abstract}

Keywords: Social Support, Achievement Motivation, and Students Engagement

\section{PENDAHULUAN}
Keterlibatan
siswa
(students' engagement) memiliki peranan penting bagi siswa untuk dapat menyelesaikan pedidikan dan memperoleh capaian atau prestasi bidang akademik yang baik. Penelitian terdahulu telah banyak yang membahas mengenai pentingnya keterlibatan siswa di sekolah dan demikian pula mengenai dampak dari ketidakterlibatan siswa di sekolah. Pada penelitian tentang

keterlibatan siswa di sekolah dan kepuasan akademik siswa menunjukkan bahwa siswa yang memiliki keterlibatan emosi dan perilaku yang tinggi memiliki perilaku bermasalah yang rendah, memiliki sense of belongingyang tinggi terhadap sekolah dan tidak terlibat pada penggunaan obat-obat terlarang ( $\mathrm{Li}, 2011)$.

Istilah keterlibatan siswa di sekolah merujuk pada partisipasi aktif yang diperlihatkan oleh siswa, sedangkan ketidakterlibatan (disengagement) siswa 
mengarah kepada perilaku negatif yang ditunjukkan oleh siswa misalnya tidak aktif dalam proses belajar, tidak mengerjakan tugas, berpindah-pidah jurusan, mengganggu teman, membolos, dan capain belajar buruk. Perilaku tersebut akan memberikan dampak negatif pula bagi siswa misalnya dikeluarkan dari sekolah, sehingga menyebabkan angka putus sekolah di Indonesia meningkat (Bennett, 2007).

Keterlibatan sis wa di sekolah merupakan sebuah konstrak yang multidimesioanal meliputi tiga komponen yakni komponen perilaku, kognitif danemosi. Pertama, Keterlibatan siswa dari segi perilaku (behavioral engagement) mengarah pada perbuatan dan tindakan yang dilakukan secara langsung oleh siswa di sekolah misalnya kehadiran, partisipasi pada kegiatan belajar, menaati aturan dan mengerjakan tugas. Kedua, keterlibatan dari segi kognitif merujuk pada kualitas proses kognitif dan strategi belajar siswa terhadap tugas sekolah misalnya kemauan dan ketekunan untuk belajar, regulasi diri dan menyukai tantangan. Ketiga, keterlibatan secara emosional mengacu pada rasa kepemilikan pada sekolah, ketertarikan, persepsi terhadap nilai belajar, reaksi positif dan negatif terhadap guru, teman dan aktivitas sekolah (Poskittand Gibbs, 2010).

Zepke, Leach and Butler's (2010) menjelaskan bahwa terdapat beberapa faktor yang mempengaruhi keterlibatan siswa di sekolah yakni motivasi internal siswa, interaksi guru-murid, interaksi sesama murid, fasilitas belajar, dukungan institusi serta non institusional lainnya seperti keluarga. Kombinasi dari faktor-faktor baik internal maupun eksternal tersebut akan mempengaruhi keterlibatan siswa baik dari segi sikap, emosi dan juga kognitif.

Secara umum permasalahan yang sering dikeluhkan oleh para pendidik yakni kurangnya dukungan atau kepedulian orang tua terhadap pendidikan anaknya. Penelitian terdahulu Sebuah penelitian kualitatif yang dilakukan pada etnis minoritas di Vietnam mengenai faktor yang menyebabkan rendahnya motivasi pendidikan pada siswa menengah atas ditemukan bahwa kurangnya keyakinan dan kepercayaan dalam fungsi sistem pendidikan, hubungan guru-murid terbatas, kurangnya keterlibatan orang tua serta kepedulian terhadap urusan sekolah anak, kurang kondusifnya lingkungan pendidikan formal dan rendahnya dukungan dari teman (Tran, 2013).
Berbeda dengan penelitian di atas, Wang dan Eccles (2013) pada penelitiannya mengungkap bahwa hubungan antara dukungan sosial dan keterlibatan siswa di sekolah merupakan hubungan yang tidak langsung, dalam hal ini hubungan keduanya melibatkan variabel intervening berupa factor karakteristik individual dan juga factor psikologis. Dari temuan tersebut, dapat dipahami bahwa hubungan antara faktor eksternal dan keterlibatan siswa di sekolah tidak secara langsung akan tetapi melalui faktor- factor baik itu karakteristik individual maupun psikologis. Oleh karena itu peneliti memilih untuk menguji factor psikologis yakni motivasi berprestasi sebagai mediasi pada hubungan antara dukungan sosial dan keterlibatan siswa di sekolah.

Motivasi sangat penting bagi seorang siswa. Dengan motivasi yang tinggi siswa dapat lebih mempersiapkan diri dalam belajar, mengarahkan kegiatan belajarnya dan akan lebih sadar untuk melakukan upaya-upaya memperoleh tujuan belajar yang ia inginkan. Motivasi siswa di kelas berkaitan dengan alasan dibalik perilaku murid dan sejauh mana perilaku mereka diberi semangat, punya arah dan dipertahankan dalam jangka lama. Jika siswa tidak menyelesaikan tugas karena bosan, maka mereka kekurangan motivasi. Namun sebaliknya jika siswa menghadapi tantangan dalam mengerjakan tugas dan menyelesaikan tanggungjawab di sekolah maka hal tersebut menggambarkan bahwa siswa tersebut memiliki motivasi besar.

Motivasi merupakan suatu proses psikologis pada diri siswa yang akan menentukan tingkatan kegiatan serta arah umum dari tingkah laku siswa, sehingga dapat mempengaruhi siswa, membangkitkan dan mengarahkan tingkahlaku yang akan ditampilkan oleh para siswa (Rahman,2012). Oleh karena itu, motivasi merupakan hal yang sangat penting dan sangat dibutuhkan dalam diri siswa. Siswa yang memiliki motivasi rendah terkadang tidak memperlihatkan usaha yang maksimal dalam pendidikannya.Tingkat motivasi berprestasi siswa akan turut berkontribusi pada tingkat keterlibatan yang ditampilkan oleh siswa di sekolah, baik kegiatan belajar maupun kegiatan sekolah lainnya.

Mclelland mengemukakan sebuah teori yakni need for achievement yang menyakini bahwa setiap indivdu pada hakikatnya memiliki kebutuhan untuk meraih prestasi atau mengungguli individu lainnya. Penelitian 
sebelumnya menunjukkan bahwa motivasi yang dimiliki oleh siswa baik secara intrinsik maupunekstrinsik mempengaruhi tinggi rendahnya keterlibatan siswa di sekolah. Keterlibatan siswa di sekolah tidak hanya ditunjukkan dengan mengerjakan tugas-tugas sekolah dengan baik tetapi usaha keras dan konsentrasi untuk memahami kontent(SaeedandZyngier, 2012).

Motivasi berprestasi memiliki efek yang signifikan terhadap keterlibatan siswa di sekolah, selanjutnya tingkat keterlibatan akan mempengaruhi capaian siswa di sekolah. Eccles (2007)mengatakan bahwa pencapaian atau prestasi yang berkaitan dengan pilihan seperti keterlibatan siswa di sekolah dipengaruhi oleh faktor psikologis, seperti ekspektasi individu untuk meraih sukses dan penilain individu terhadap kegiatan-kegiatan akademik. Motivasi berprestasi memiliki efek yang sangat signifikan terhadap keterlibatan siswa pada akademiknya. Tingkat keterlibatan antara siswa yang memiliki motivasi berprestasi tinggi dengan siswa yang memiliki keterlibatan rendah tentu akan menunjukkan perbedaan (Wormington, Corpus and Anderson, 2011).

Beberapa penelitian terdahulu seperti yang telah dipaparkan pada paragraph sebelumnya menguji hubungan langsung baik itu dukungan sosial, dukungan emosional maupun motivasi berprestasi secara langsung terhadap keterlibatan siswa disekolah. Namun pada penelitian ini, peneliti menguji hubungan tersebut dengan menggunakan variabel intervening. Selain itu terdapat pula penelitian sebelumnya yang menguji hubungan antara dukungan guru dan teman sebaya dengan keterlibatan siswa di sekolah yang menggunakan variable intervening berupa karakteistik individual dan faktor-faktor psikologis. Sedangkan pada penelitian ini, peneliti lebih berfokus pada dukungan social baik itu dari orangtua, guru dan teman.

Penelitian ini bertujuan menguji peran variabel intervening berupa mediasi pada hubungan antara dukungan social dengan keterlibatan siswa disekolah. Dengan demikian penelitian ini ingin menguji apakah hubungan antara dukungan orangtua, guru, teman sebaya dan keterlibatan siswa di sekolah merupakan hubungan langsung atau hubungan tidak langsung.

Manfaat yang diharapkan melalui penelitian ini ada dua yakni manfaat teoritis dan manfaat praktis. Manfaat teoritis penelitian ini yakni memberikan masukan teoritis untuk menambah khasanah keilmuan dalam pengembangan bidang ilmu Psikologi khususnya pada Psikologi pedidikan, sehingga dapat digunakan sebagai referensi dalam penelitian selanjutnya. Manfaat praktis pada penelitian ini diharapkan bahwa professional yang terkait serta lingkungan sekitar agar dapat mengupayakan solusi pencegahan terhadap permasalahan tingkat keterlibatan siswa pada aktivitas sekolah sehingga mampu mereduksi kompleksnya permasalahan dalam dunia pendidikan yang disebabkan oleh rendahnya keterlibatan siswa.

Penelitian ini menggunakan hipotesis yaitu : 1) Terdapat hubungan $\mathrm{p}$ o s i t i f antara dukungan sosial(orangtua, guru dan teman)dengan keterlibatan siswa di sekolah 2) Terdapat hubungan antara dukungan sosial dengan motivasi berprestasi 3) Hubungan antara dukungan social dan keterlibatan siswa di sekolah dimediasi oleh motivasi berprestasi.

\section{METODE}

Penelitian ini terdiri dari tiga variabel yakni dukungan social, keterlibatan siswa di sekolah dan variabel mediasi yakni motivasi berprestasi. Pengujian hubungan antar variabel pada penelitian ini menggunakan desain korelasional. Desain korelasional tersebut digunakan untuk menguji hubungan antar variabel penelitian baik hubungan secara langsung amupunn hubungan tidak langsung. Penelitian ini menguji peranan variabel mediasi yakni motivasi berprestasi pada hubungan antar dukungan sosial dan keterlibatan siswa di sekolah.

Penelitian ini dilaksanakan di SMA Neg. 3 Palopo tepatnya pada siswa kelas XII IPA dan IPS. Sebanyak 120 orang siswa dipilih dengan menggunakan teknik "proporsional Sampling", siswa yang terpilih kemudian diberikan angket untuk diisi sesuai instruksi peneliti.

Variabel keterlibatan siswa di sekolah diukur menggunakan skala yang dikembangkan oleh Wang dan Holcomble (2010) yakni The school engagement index. Skala tersebut mengukur pada tiga dimensi yakni dimensi kognitif mengacu pada strategi (regulasi diri) yang digunakan dalam mengerjakan tugas. Dimensi affective mengacu pada perasaan menyukai kegiatan belajar dan perasaan positif terhadap sekolah. Sedangkan dimensi behavior meliputi usaha yang diperlihatkan pada saat mengerjakan tugas dan pada saat di lingkungan 
sekolah. Skala asli terdiri dari 14 aitem, setelah dilakukan try out maka terdapat 3 aitem yang gugur sehingga diperoleh nilai reliabilitas sebesar 0.720 .

Dukungan social pada penelitian ini diukur dengan menggunakan skala child and adolescent social support(CASS)yang disusun olehMalecki, Demaray and Elliot pada tahun 2002. Pada skala asli terdapat 36 aitem yang mewakili aspek dukungan orangtua, guru dan teman sebaya(White, 2009). Setelah dilakukan try out, maka diperoleh koefisien reliabilitas sebesar 0.883 dan 6 item dinyatakan gugur atau tidak dapat digunakan pada penelitian ini. Variabel mediasi diukur dengan menggunakan skala motivasi yang dikembangkan oleh Ellez (2004). Skala tersebut terdiri dari 23 aitem dengan pilihan jawaban yakni sangat setuju, setuju, tidak setuju dan sangat tidak setuju. Setelah dilakukan uji coba, maka terdapat 8 aitem yang gugur sehingga hanya tersisa 15 aitem saja yang digunakan dalam penelitian ini dan nilai koefisien reliabilitas sebesar 0.783 .

Hipotesis penelitian diuji dengan menggunakan analisis jalur (PathAnalysis), yang bertujuan untuk mengetahui hubungan antar variabel baik secara langsung maupun secara tidak langsung (Sudaryono,2011). Pengujian hipotesis pada penelitian ini menekankan untuk menguji hubungan langsung antara dukungan sosial dan keterlibatan siswa di sekolah dan juga hubungan tidak langsung yakni hubungan tersebut melalui variabel intervening berupa variabel mediasi. Analisis data pada penelitian ini dilakukandengan menggunakan alat bantu komputer dengan program SPSS(Statisticalpackagesforsocial science).

\section{HASIL DAN PEMBAHASAN}

\section{Deskripsi Variabel Penelitian}

Hasil deskripsi statistik dukungan sosial, motivasi berprestasi dan keterlibatan siswa di sekolah dapat ditunjukkan pada tabel sebagai berikut.

Tabel 1. Deskripsi variabel penelitian

\begin{tabular}{cccc}
\hline Variabel & Range & M & SD \\
\hline Dukungan_Sosial & $30-120$ & 79.44 & 7.20 \\
Motivasi_Berprestasi & $15-60$ & 39.86 & 5.95 \\
Keterlibatan_Siswa & $11-44$ & 32.61 & 4.01 \\
\hline
\end{tabular}

Pada tabel 1 di atas dapat diketahui bahwa tingkat keterlibatan subjek penelitian ini berada pada kategori tinggi dengan nilai $\mathrm{M}=32.61$, sedangkan untuk dukungan sosial yang didapatkan oleh siswa dari orangtua, guru dan teman sebayanya berada pada kategori sedang ( $\mathrm{M}$ $=79.44)$ dan motivasi berprestasi yang dimiliki oleh subjek pada penelitian ini berada pada kategori sedang $(\mathrm{M}=39.86)$.

\section{Korelasi Antar Variabel Penelitian}

Untuk mengetahui hubungan antar variabel pada penelitian ini dapat dilihat dari angka korelasi antarvariabel penelitian. Hubungan antara variabel pada penelitian ini dapat dilihat pada tabel 2 berikut ini.

Tabel 2. Hasil Uji Korelasi antar Variabel

\begin{tabular}{lccc}
\hline \multicolumn{1}{c}{ Variabel } & $\begin{array}{c}\text { Dukungan } \\
\text { Sosial }\end{array}$ & $\begin{array}{c}\text { Motivasi } \\
\text { berprestasi }\end{array}$ & Keterlibatan siswa \\
\hline Dukungansosial & 1 & $\mathbf{0 . 6 9 0}^{* * *}$ & $\mathbf{0 . 6 8 1}^{* * *}$ \\
Motivasiberprestasi & & & $\mathbf{0 , 5 3 9}^{* *}$ \\
Keterlibatan siswa & & & 1 \\
\hline
\end{tabular}

** Correlation is significant at the 0.01 level (2-tailed).

Tabel 2 di atas menjelaskan bahwa hubungan antara dukungan sosial dengan motivasi berprestasi menunjukkan hubungan positif yang signifikan $(r=0,690 ; p<0.01)$. Hal tersebut menjelaskan bahwa jika siswa mendapatkan dukungan penuh dari orang tua, guru dan teman sebaya akan memjadi faktor yang 
mendukung tingginya motivasi berpretasi yang dimiliki siswa.

Demikian halnya dengan hubungan antara dukungan orangtua, guru dan teman sebaya dengan keterlibatan siswa di sekolah juga terlihat adanyakorelasi positif yang signifikan $(\mathrm{r}=0,681 ; \mathrm{p}<0,01)$. Dari hasil tersebut mengindikasikan bahwa dukungan sosial dari orang tua, guru dan teman akan menyebabkan tingginya keinginan siswa untuk terlibat aktif pada kegiatan akademik di sekolah.

Hubungan antara motivasi berprestasi dengan keterlibatan siswa di sekolah juga menunjukkan hubungan positif yang signifikan $(\mathrm{r}=0,539 ; \mathrm{p}<0,01)$ hal tersebut mengindikasikan bahwa semakin tinggi motivasi berprestasi yang dimiliki oleh siswa maka akan menyebabkan siswa memiliki keinginan untuk terlibat aktif pada kegiatan-kegiatan di sekolah, baik kegiatan di dalam kelas maupun di luar kelas yang pada akhirnya akan mempengaruhi capaian belajar siswa.

Hasil regresi antara dukungan sosial dengan keterlibatan siswa di sekolah dan juga variabel motivasi berprestasi dengan keterlibatan siswa di sekolah dapat dilihat pada tabel berikut.

Tabel 3. Hasil Uji Regresi antar Variabel

\begin{tabular}{lcrl}
\hline \multicolumn{1}{c}{ Variabel } & B & Sig \\
\hline Konstanta & & & \\
Dukungan Sosial & 0,590 & .000 \\
Motivasi Berprestasi & 0,132 & .000 \\
\hline
\end{tabular}

Tabel 3 menunjukkan hasil uji regresi dukungan sosial (orangtua, guru dan teman) dengan keterlibatan siswa diperoleh nilai $\beta=0,590$. Nilai hubungan antara variabel tersebut positif yang artinya bahwa semakin tinggi orangorang terdekat siswa memberikan dukungan terhadap siswa maka semakin tinggipula keterlibatan siswa pada kegiatan akademik di sekolah. Sebaliknya jika orangtua, teman dan guru kurang memberikan dukungan maka akan menyebabkan siswa memiliki tingkat keterlibatan yang rendah.

Hasil uji regresi motivasi berprestasi dengan keterlibatan siswa diperoleh nilai

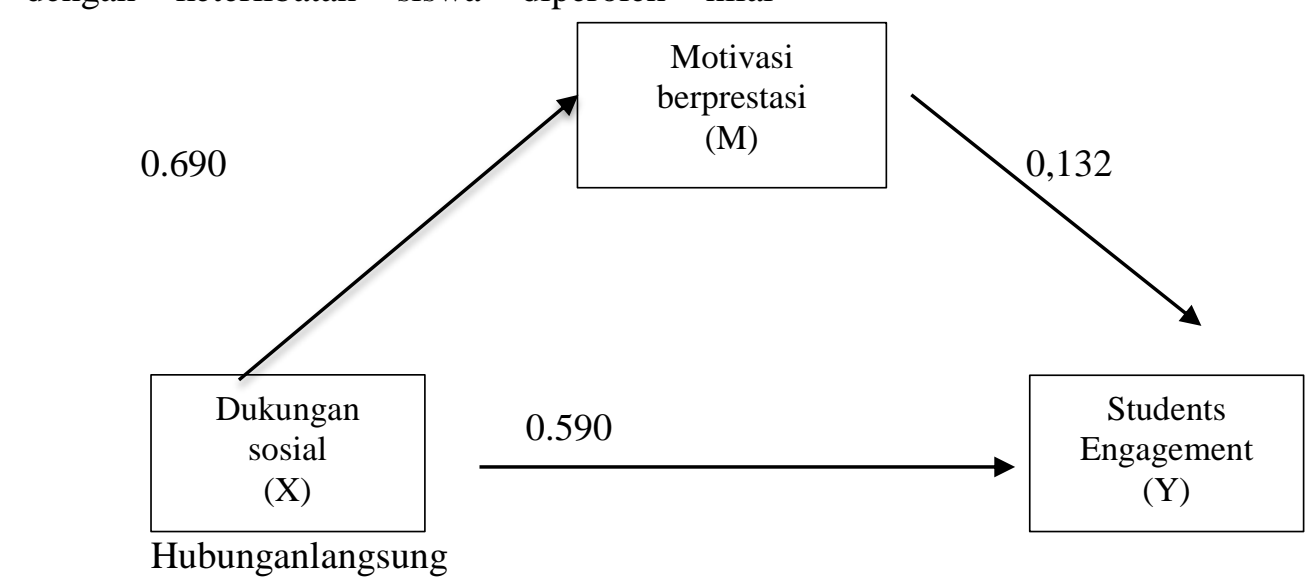

Hasil nilai determinan antar ketiga variabel pada penelitian ini dapat didefenisikan sebagai berikut : a). Hubungan langsung antara dukungan $\beta=0,132$. Nilai hubungannya juga positif yang menjelaskan bahwa tingkat motivasi berprestasi yang dimiliki siswa akan berpengaruh terhadap tingkat keterlibatan siswa pada kegiatan-kegiatan di sekolah dan demikian pula sebaliknya jika motivasi berprestasi rendah maka akan mengakibatkan siswa bermalas-malasan dalam mengikuti kegiatan di sekolah. Koefisien jalur dukungan sosial terhadap keterlibatan siswa dan motivasi berprestasi terhadap keterlibatan siswa ditunjukkan dalam bentuk gambar sebagai berikut:

\section{Gambar 1.Koefisien Jalur antar Variabel}

sosial dan keterlibatan siswa di sekolah dilihat dari nilai determinan keduanya terlihat nilai koefisien jalurnya yaitu $0,590 \mathrm{~b}$ ). Hubungan tidak 
langsung, nilai determinan dukungan sosial dan keterlibatan siswa di sekolah dimediasi oleh motivasi berprestasi harus dihitung dengan mengalikan koefisien tidak langsungnya yakni $0,690 \times 0,132=0,091$ dan $\mathrm{c})$. Total nilai determinan dukungan sosial, motivasi berprestasi dan keterlibatan siswa yakni $0,590+0,091=0,681$ atau $68.1 \%$.

Berdasarkan perbandingan nilai determinan antara hubungan langsung dan tidak langsung diperoleh bahwa 0,590 $(59,0 \%)>0,091$ (9.1\%). Hasil tersebut menunjukkan bahwa nilai hubungan langsung lebih besar dibandingkan dengan nilai hubungan tidak langsung, sehingga dapat disimpulkan bahwa variabel motivasi berprestasi tidak berfungsi sebagai mediator pada hubungan antara dukungan sosial dan keterlibatan siswa di sekolah atau dapat dikatakan bahwa hubungan antara dukungan sosial dan keterlibatan siswa di sekolah merupakan hubungan langsung.

\section{Pembahasan}

Hasil penelitian ini menemukan bahwa terdapat korelasi positif antara dukungan sosial, motivasi berprestasi dan keterlibatan siswa di sekolah, hal tersebut memiliki makna bahwa tinggi-rendahnya dukungan sosial yang dirasakan oleh siswa baik dari orang tua, guru dan teman akan berdampak pada kualitas motivasi berprestasi yang dimiliki oleh siswa dan seterusnya juga akan berdampak pada tingkat keterlibatan siswa pada kegiatan-kegiatan di sekolah. Oleh karenanya seluruh stake holder di sekitar siswa harus menyadari betapa pentingnya memberikan dukungan kepada siswa baik dukungan moril maupun materil.

Hasil penelitian di atas diperkuat oleh teori sistem ekologi yang mengemukakan bahwa paling tidak terdapat tiga konteks lingkungan sosial yang sangat berhubungan dengan keterlibatan siswa di sekolah yakni keluarga, teman dan guru. Orang tua yang memberikan dukungan kepada anak mereka dan memiliki ekspektasi akademik yang tinggi terhadap anak akan mendorong anak tersebut untuk berjuang mendapatkan hasil yang terbaik. Demikian halnya dengan teman sebaya juga turut berpengaruh pada persepsi, sikap dan perilaku siswa terhadap sekolah yang tentunya akan berefek pada keputusan siswa untuk terlibat aktif atau bahkan tidak terlibat pada kegiatan- kegiatan akademik di sekolah. di lingkungan sekolah, guru memiliki peran yang sangat penting untuk meningkatkan keterlibatan siswa. Peran-peran itu seperti menggunakan metode mengajar yang menarik, menciptakan iklim kelas yang kondusif dan terbuka untuk berinteraksi dengan siswa (Fernández-Zabala, Goni E, Camino I and Zulaika, 2015).

Ketiga komponen lingkungan sosial tersebut memiliki peran yang berbeda-beda akan tetapi harus saling bersinergi dalam menjalankan peranannya, sehingga dapat memotivasi siswa terlibat aktif pada proses akademiknya.

Dukungan yang diterima oleh siswa dari orang-orang disekitarnya dapat menyebabkan siswa merasa percaya diri, memotivasi dan mengurangi kecemasan siswa pada tantangan yang dihadapi dalam proses belajar (Cirik, 2015). Groves, Sellars, Smith and Barber (2015) menjelaskan bahwa untuk mendorong agar siswa terlibat aktif maka guru harus antusias, melakukan persiapan dengan baik, terbuka, berdiskusi tentang progres siswa, menantang sejauh mana siswa mampu melakukan hal-hal yang berkaitan dengan akademik mereka. Selain itu guru juga berperan penting untuk memberikan stimulus terhadap hubungan antar sesama siswa misalnya, meminta siswa untuk belajar bersama dan menerapkan sistem pembelajaran aktif kolaboratif. Siswa yang memiliki hubungan baik dengan temannya akan terhindar dari perasaan terasing dan akan melibatkan diri secara aktif pada kegiatan akademiknya.

Hasil penelitian ini juga memperlihatkan bahwa motivasi berprestasi memiliki korelasi positif dengan keterlibatan siswa di sekolah yang artinya bahwa ketika siswa memiliki motivasi berprestasi tinggi tentu akan lebih terlibat aktif pada kegiatan akademik.Motivasi merupakan pendorong bagi setiap individu untuk melakukan sesuatu sedangkan keterlibatan secara aktif merupakan hasil dari dorongan tersebut. Oleh karena itu tugas guru di sekolah yakni menumbuhkan motivasi siswa sehingga siswa memiliki kemauan untuk berpartisiasi secara aktif di sekolah.

Hasil penelitian ini juga menunjukkan bahwa motivasi berprestasi tidak berfungsi sebagai mediator hubungan antara dukungan sosial dan keterlibatan siswa di sekolah. Hal tersebut dapat dilihat dari perbandingan nilai determinan hubungan langsung yang lebih besar dibandingkan nilai determinan hubungan tidak langsung. Dukungan sosial memiliki hubungan langsung yang signifikan dengan keterlibatan siswa, demikian pula dengan motivasi berprestasi memiliki hubungan dengan keterlibatan siswa di sekolah. Namun, motivasi berprestasi tidak berperan sebagai mediator. 
Murray mengemukakan sebuah teori yang dikenal dengan need for achievement untuk mengkaji permasalahan motivasi berprestasi. Murray berpendapat bahwa motivasi berprestasi merupakan sebuah konstrak yang kurang konsisten sehingga diperkirakan akan memicu perilaku yang berbeda pada setiap situasi. Mclelland menambahkan bahwa motivasi berprestasi merupakan hasil konflik emosional antara harapan untuk sukses dan keinginan untuk menghindari kegagalan.Harapan untuk sukses berkaitan dengan emosi positif dan keyakinan untuk sukses, sementara keinginan untuk menghindari kegagalan berkaitan dengan emosi negatif (Steinmayr and Spinath, 2009).

Motivasi berprestasi merupakan sebuah konstrak yang kurang konsisten dan dapat berubah-ubah sehingga motivasi yang dimiliki oleh individu dapat saja berubah dalamhitungan waktu yang singkat dan dapat pula terjadi perbedaan motivasi pada satu bidang studi dengan bidang studi lainnya. Sebagai contoh dalam proses belajar-mengajar terkadang siswa nampak sangat tekun pada satu bidang studi namun pada bidang studi lainnya siswa tersebut nampak kurang semangat dan kurang berpartisipasi. Oleh karena itu motivasi berprestasi tidak dapat berfungsi sebagai mediator pada hubungan antar variabel penelitian tersebut. Hal tersebut sejalan dengan beberapa hasil penelitian yang menemukan bahwa hubungan antara lingkungan keluarga, konteks sekolah dan keterlibatan siswa atau prestasi akademik dimediasi oleh faktor psikologis yang sifatnya konsisten misalnya efikasi diri dan konsep diri akademik (Buhs,2005; Flook, Repetti and Ullman, 2005).

\section{SIMPULAN DAN SARAN}

Dari hasil penelitian ini dapat disimpulkan bahwa terdapat hubungan positif yang signifikan antara dukungan sosial dengan keterlibatan siswa di sekolah dan demikian pula antara dukungan sosial dengan motivasi berprestasi siswa memiliki hubungan positif yang signifikan

Hipotesis 3 ditolak. Hal tersebut dapat dilihat dari hubungan langsung antara dukungan sosial dengan keterlibatan siswa lebih besar dibandingkan hubungan tidak langsung, yang berarti bahwa motivasi berprestasi tidak sebagai mediator pada hubungan antara dukungan sosial dengan keterlibatan siswa di sekolah.

Dari hasil penelitian ini, peneliti merekomendasikan kepada peneliti selanjutnya agar menguji atau menganalisa faktor lain khususnya variabel intervening (mediasi maupun moderasi) untuk mengetahui hubungan langsung ataupun tidak langsung pada variabel-variabel penelitian ini. Selain itu juga disarankan untuk menspesifikkan pengukuran keterlibatan siswa pada satu disiplin ilmu saja.

\section{REFERENSI}

Bennett J. (2007). Work-based learning and social support: Relative influences on high school seniors' occupational engagement orientations. Career and Technical Education Research, 32(2), 187-214. https://doi.org/10.1177/0894845314543 496

Buhs, E. S. (2005). Peer rejection, negative peer treatment, andschool adjustment: Selfconcept and classroom engagementas mediating processes. Journal of School Psychology, 43(5),407-424.

Cirik, I. (2015). Relationships between social support, motivation and science achievement: Structural equation modeling. Anthropologist, 20(2), 232-242.

Fernández-Zabala, A., Goni.E., Camino, I and Zulaika. L. M., (2015). Family and school context in school engagement.European Journal of Education and Psychology.http://dx.doi.org/10.1016/j.eje ps.2015.09.001

Flook, L., Repetti, R. L., \& Ullman, J. B. (2005).Classroomsocial experiences as predictors of academic performance.Developmental Psychology, 41(2), 319---327.

Gunuc,

S.(2014).Therelationshipbetweenstudente ngagementandtheir academic achievement.International Journal on New Trends in Education and Their Implications, 5(4), 216-231.

Garcia-Reid,P.(2007). Examining social capital as a mechanism for improving school engagement among low income Hispanic girls. Youth Society, 39(2), 164-181.

Groves, M., Sellars, M., Smith, J., \& Barber, A. (2015). Factors affecting student engagement: A case study examining two cohorts of students attending a post-1992 University in the United Kingdom. International Journal of Higher Education, 4(2), 27-37. 
Galugu, Amriani. Motivasi berprestasi sebagai mediasi...

Martin, A. J. (2010). Girls, achievement motivation and the glass ceiling. Implications for personal potential. Summary of Keynote at The Alliance of Girls' Schools Australasia Conference. Lifelong Achievement Group.www.lifelongachievement.com.

Poskitt,J.,\& Gibbs,R. (2010). Student engagement in the middle years of schooling (Years7-10): A literature review. Literature Review. Report to the Ministry of Education(Evaluation Associates Ltd Massey University).

Rahman, A.R. (2012). Pengaruh motivasi, lingkungan dan disiplin terhadap prestasi belajar siswa pada jurusan teknik audio video Yogyakarta. Retrieved January 22,2016 from http://eprints.uny.ac.id/9495/1/Jurnal.pdf.

Steinmayr,R.,\&Spinath,B.(2009). The importance of motivation as a predictor of school achievement. Learning and Individual Differences, 19, 80-90.

Saeed, S., \&Zyngier, D. (2012). Howmotivation influences student engagement: Aqualitative casestudy. Journal of Education and Learning, 1(2), 252-267.

Suárez-Orozco, C., Pimentel, A., \& Martin, M. (2009).The significance of relations. Academia engagement and achievement among newcomer immigrant youth.Teacher College Record,111(3), 712-749.

Sudaryono.(2011).

Aplikasi analisis(PathAnalysis) berdasarkan urutan penempatan variabel dalam penelitian. Jurnal Pendidikan dan Kebudayaan, 17, 391-403.

Tran, N. T. (2013). Factors associated with low educational motivation among ethnic minority students in Vietnam. Ritsumeikan Journal of Asia Pacific Studies, 32, 124136.

Wang,M.T.,\& Holcombe,R.(2010). Adolescents' perceptions of school environment, engagement, and academic achievement in middle school. American Educational Research Journal, 47, 633-662.

Warmington, S.V., Corpus, J. H., \& Anderson. (2011). Running head: Motivation in high school setting. Paper Presented At The Annual Meeting of The American
Educational Research Association. New Orleans, LA.

White,T.N.(2009).The influence of perceived social support from parents, classmates, and teachers on early adolescents' mental health. Graduate Theses and Dissertations. Retrieved from http://scholarcommons.usf.edu/etd/82.

Wang, M.T.,\&Eccles, J. S. (2013).School Context, Achievement Motivation, and Academic Engagement: A Longitudinal Study of School Engagement Using a Multidimensional Perspective. Learning and Instruction, 28, 12-23.

Wang,M.T.,\& Holcombe,R.(2010). Adolescents'perceptions of school environment, engagement, and academic achievement in middles chool. American Educational Research Journal, 47, 633662.

Zepke, N., L. Leach, \& P. Butler. (2010). Student engagement: What is it and what influences it? Wellington, Teaching and Learning Research Initiative. http://www.tlri.org.nz/sites/default/files/pr ojects/9261-Introduction.pdf 